\title{
Genetic distance and diversity of breadfruit (Artocarpus altilis) based on morphological characters in Bawean Island, Indonesia
}

\author{
WARDATUR RAHMAH, BUDI WALUYO \\ Department of Agronomy, Faculty of Agriculture, Universitas Brawijaya. Jl. Veteran, Malang 65145 East Java, Indonesia. \\ Tel.: +62-341-569984`email: budiwaluyo@ub.ac.id
}

Manuscript received: 23 August 2019. Revision accepted: 23 October 2019.

\begin{abstract}
Rahmah W, Waluyo B. 2019. Genetic distance and diversity of breadfruit (Artocarpus altilis) based on morphological characters in Bawean Island, Indonesia. Biodiversitas 20: 3284-3291. One of the ways to preserve species germplasm is by identifying the genetic distance and intraspecific diversity. The aims of this study was to study the distribution and cultivation status, genetic distance, and diversity of breadfruit plants, Artocarpus altilis (Parkinson ex F.A.Zorn) Fosberg, in Bawean Island, Gresik, Indonesia based on morphological characters. The study made 30 accessions of breadfruit plants spread throughout Bawean Island, which were found to be neither cultivated intensively nor used optimally by the inhabitants. The genetic distance showed that breadfruit in Bawean Island was clustered into 6 groups with similarity coefficient of around 0.9984 to 0.9999 . The diversity index value of 1.48 indicated medium diversity of breadfruit on this island.
\end{abstract}

Keywords: Artocarpus altilis, Bawean, diversity, genetic distance, morphological characters

\section{INTRODUCTION}

Breadfruit [Artocarpus altilis (Parkinson ex F.A.Zorn) Fosberg] is a horticulture plant having similar nutritional composition to that of rice, therefore it is sometimes seen as substitute for rice in some parts of the world (Ijarotimi and Aroge 2005; USDA 2018a,b). Breadfruit trees do not only have the ability to adapt, but also to thrive in conditions where other crops could not survive (NTBG 2019), besides being a prolific producer of nutritious fruits. This plant is a staple food in Pacific Belt and an important element in the socio-cultural rituals and system of medicine (Langton and Lincoln 2018).

Breadfruit has global distribution and its grown in more than 90 countries (Badrie and Brooms 2010) with varied vernacular names viz. it is called sukun (Indonesia), kapiak (Papua New Guinea), breadfruit (English), bakri-chajar (Hindi, India), Nagadamini (Sanskrit, India), rimas (Philippines), kulur/curor (Malaysia), brotfruchtbaum (Germany), arbre à pain (French), árbol del pan (Spain), utol kulu (Fiji), bialnimbalu (Solomon Island), beta (Vanuatu), ulu (Hawaii, Samoa), uru (Tahiti), kuru (Cook Island), and lemai (Mariana Islands) etc. (Ragone 1997). Breadfruit are known to occur throughout Indonesia, however, according to the variety release database (Pusat Perlindungan Varietas Tanaman dan Perizinan Pertanian 2019 ), there are only 3 released varieties and 4 varieties that have been registered. One of the released varieties of breadfruit is Manis Variety which is registered under the government of Tanah Datar, West Sumatra. Nevertheless, the said registration database shows that the breadfruit varieties were obtained originally from Bawean Island
(Sistem Informasi Database Varietas Tanaman Kementerian Pertanian R.I. 2019). Therefore, it indicated that Bawean Island to be breadfruit diversity rich area in Indonesia.

Bawean is one of the small islands located in the north of Java Island under the administrative control of Gresik, East Java. Although breadfruits are distributed throughout this island, the breadfruit varieties like Manis which is native to this Island have neither been registered as local variety nor brought under breeding programs Primary reason behind such negligence could be due to lack of proper management of breadfruit germplasm by the local people of Bawean Island as well the issue less prioritized by the local government of Gresik.

If timely germplasm management and conservation initiatives are not taken, the breadfruit germplasm may get threatened in Bawean Island. However, to understand what we are going to manage, beforehand we need to know what resource(s) we have left for management. One of the ways to conserve the breadfruit germplasm is by identifying the genetic distance and diversity of breadfruit in Bawean Island. The identification is expected to be an early stage in the release of local varieties and varieties of breeding yield of Bawean breadfruit so that breadfruit in Bawean Island can be utilized optimally by the inhabitants.

Therefore, this study aims to determine: the distribution and cultivation status of breadfruit in Bawean Island, to determine the genetic distance based on morphological characters, and to determine the diversity of breadfruit plants in Bawean Island based on morphological characters. 


\section{MATERIALS AND METHODS}

\section{Study area}

This study was conducted from January to April 2019 in Bawean Island (Latitude $5^{\circ} 40^{\prime}$ to $5^{\circ} 50^{\prime}$, Longitude $112^{\circ} 3^{\prime}$ to $112^{\circ} 36^{\prime}$ ) which is a small island located between Java and Kalimantan Islands and is under administrative area of Gresik District, East Java Province, Indonesia; 19 villages in two subdistricts, i.e. Sangkapura and Tambak were surveyed in this research (Table 1, Figure 1). The island has an elevation from 0 to $655 \mathrm{~m}$ asl. and has temperatures varying around $23^{\circ} \mathrm{C}$ to $33^{\circ} \mathrm{C}$. Average humidity in the Island ranges from $67 \%$ to $95 \%$ (BMKG 2019).

\section{Sampling and data collection}

This study was gradually carried out by survey method (plant observations and semi-structured interviews). Initially, information from the local residents was sought about the existence of breadfruit plants in Bawean Island. Breadfruit plants were sampled with convenience sampling method. Convenience sampling is one of the sampling methods based on the probabilities put forward in several practical criteria such as easy accessibility, geographical proximity, or time schedule in accordance with the research objectives (Etikan et al. 2016). In the current study, the locations were divided into 4 areas, then $\geq 3$ plant samples were observed plants for each area. The details of the locational are as follows: (i) First area: Kota Kusuma, Sungaiteluk, Patar Selamat, Bululanjang, Pudakit Barat, Pudakit Timur, Lebak, Kumalasa, Suwari and Deket Agung, (ii) Second area: Sawah Mulya, Daun, Sungairujing, Gunung Teguh, Balikterus, Kebun Teluk Dalam and Sidogedung Batu, (iii) Third area: Teluk Jatidawang, Gelam, Sukaoneng, Kelumpanggubug, Sukalila, Tambak and Grejeg, (iv) Fourth area: Tanjungori, Paromaan, Dipongo, Kepuhteluk and Kepuh Legundi

In the next step, plant observations were made to note down morphological features (both qualitative and quantitative) and semi-structured interviews with owners of the plants were undertaken to find out information about the cultivation status of breadfruit in Bawean Island.

For plant observations, breadfruit plant descriptors according to Ragone and Wiseman (2007) and Jones et al. (2013) were followed and observations were made by inspecting the qualitative and quantitative characters in the leaf, flower, and fruit of breadfruit plants. Observation of the leaves was done on the fully expanded leaves located three points from the distal end of branch. Observation of the flowers was done on the mature male flower. Similarly, mature but not yet ripe fruits were observed for characteristics. The details of the qualitative and quantitative characters of breadfruit plants of Bawean Island are as follows: (i) Qualitative characters: crown shape, leaf dissection, leaf colour, leaf surface, shape of leaf apex, shape of leaf base, vein colour, fruit shape, skin texture, skin colour, scabbing between skin section, scabbing in center of skin section, scabbing colour between skin section, scabbing colour in center of skin section, flesh colour and colour of latex. (ii) Quantitative characters: leaf length, leaf width, number of lobes, length of lobes, width of lobes, sinus depth, petiole length, petiole diameter, flower length, flower diameter, fruit weight, fruit length, fruit width at middle, fruit width at top, fruit width at bottom, core length, core diameter and peduncle length.

\section{Data analysis}

Analysis of breadfruit distribution was done by recording the coordinates of the breadfruit plant location by Avenza Maps application version 3.7.1 and then presented as maps made by Desktop ArcGIS application (version 10.3). Cultivation status of breadfruit in Bawean Island was explained descriptively based on the results of interviews with breadfruit tree owners. Genetic distance analysis was performed by using agglomerative hierarchical clustering (AHC) based on similarities with the unweighted pair group method with the arithmetic average (UPGMA) (Mohammadi and Prasanna 2003). Analysis of the genetic distance of breadfruit plants was carried out by XLSTAT software (version 2014.5.03). The results of genetic distance analysis were presented in the form of dendrogram. Analysis of breadfruit diversity was conducted by using the Shannon-Wiener diversity index $\left(H^{\prime}\right)$ (Magurran 1988):

$$
H^{\prime}=-{ }_{\Sigma}(p i)(\ln p i)
$$

Where: $H^{\prime}=$ Diversity index value, and $p i=$ proportion of each species. Value classification of Shannon-Wiener index is as follows: (i) $H^{\prime}<1.0 \quad=$ Low diversity, (ii) $1.0<H^{\prime}<3.322=$ Medium diversity, (iii) $H^{\prime}>3.322=$ High diversity.

\section{RESULTS AND DISCUSSION}

\section{Distribution, cultivation status and utilization of breadfruit in Bawean Island}

During the study, 30 accessions of breadfruit samples were obtained from Bawean Island (13 accessions from Sangkapura Subdistrict and 17 accessions from Tambak Subdistrict (Table 1, Figure 1).

It was found that the most favorable factor for the sustenance and spread of breadfruit plants in Bawean Islands (as noticed and revealed through interviews) was the environmental conditions of the Island (BMKG 2019). It was corroborated with the other studies which also suggest that the breadfruit plants can grow at altitudes 01550 masl with a temperature of $5^{\circ} \mathrm{C}$ to $40^{\circ} \mathrm{C}$ (Ragone 2006), and has good growth in the temperature range of $21^{\circ} \mathrm{C}$ to $32^{\circ} \mathrm{C}$ (Roberts-Nkrumah 2015). It was observed that the cultivation of breadfruit plants in the Island was not much in practice and also the 30 sampled accessions were found to be growing without special treatments like fertilization, irrigation or pest and disease management. The majority of the fruits obtained were consumed by the tree owners and given to their neighbors but not put forth for selling and only fruits from 8 accessions were harvested (when mature but not ripe) by the owners to the middlemen. It was also noticed that breadfruit plants in Bawean Island were used only used as snacks such as 
chips, boiled breadfruit, cakar-cakar and fried breadfruit, whereas as the name suggests. Breadfruit has huge potential of its processing into flour which can further be processed into variety of food items. Olaoye et al. (2007) explained that the addition of breadfruit flour in biscuit production can improve the quality of biscuits, especially its crude fiber content. According to Tamegnon et al. (2017), breadfruit from Benin is rich in fiber that can be used as porridge, donuts, croquettes, soups, and others. Besides, breadfruit contains phenolic compounds including triterpenes and flavonoids which have antimicrobial properties and hence provide medicinal benefits to those consuming it (Badrie and Broomes 2010).

\section{Morphological variation}

Breadfruit plants in Bawean Island have morphological variations. These variations were recorded from the observations on qualitative and quantitative characters in 30 accessions of sampled plants. The observations showed that crown of breadfruit in Bawean Island was variously shaped like pyramidal, wide pyramid, elliptical and irregular (Figure 2.A-D).

Breadfruits in Bawean Island had glossy to dull, green and dark green leaves with moderately dissected and deeply dissected leaves (Figure 3). However, all accessions observed have a diamond shape of leaf apex with no variation. But the observation of the leaf base shows variations in form of acute, rounded and cuneate shapes. Observations on the vein color show that breadfruit plants in Bawean Island have green, yellow-green or yellow veins.

The results of observations on the quantitative character of the leaves also indicate the variations. Breadfruit plants in Bawean Island have leaf length ranging $37 \mathrm{~cm}$ to $78 \mathrm{~cm}$, leaf width ranging $28 \mathrm{~cm}$ to $64 \mathrm{~cm}$. Breadfruit leaves in Bawean Island have lobes with a total of 7 to 9 lobes with lobe length reaching $32.2 \mathrm{~cm}$ and lobe width reaching 14.5 . The depth of the breadfruit sinus in Bawean Island is between $1 \mathrm{~cm}$ and $4 \mathrm{~cm}$. Leaf breadfruit Bawean Island has a leaf stalk with a length ranging from $3.5 \mathrm{~cm}$ to $9 \mathrm{~cm}$ and the width of the petiole ranges from $0,5 \mathrm{~cm}$ to $2 \mathrm{~cm}$.

Observations of flower and fruit showed that the breadfruit plants in Bawean Island did not fruit and flower at the same time. From 30 plant accessions observed, only 16 accessions were fruiting and 1 accession was flowering. The flowering accessions are TJO accessions with a length of $20 \mathrm{~cm}$ and a width of $3 \mathrm{~cm}$.

The breadfruit shape characters observed were spherical, broadly ovoid, oval, oblong, ellipsoid and heartshape (Figure 4). From the observation of the fruit skin texture, it was found that the breadfruit plants had smooth and flattened pebbly skin texture fruit. Observations on skin color of fruit also showed variations. The variation was light green and yellow-green. Observations on the surface of the breadfruits skin showed a variety of scab characters both in the scabbing character between the skin section and the scabbing character in center of the skin section. On the skin surface of the fruit drawn many fields in the form of 5 to 7 square structures. The scab which is between the square plane is called scabbing between skin sections. While the scab in the middle of each field is called the scabbing in center of skin section. The variations of scabbing between skin sections were no scabbing, few, medium and many. Observation on scabbing in the center of the skin section shows that breadfruit skin has a scabbing in the center of the skin section with few, medium and many traits. The next observed character is the scabbing color between the skin section and the scabbing color in center of the skin section. Observations on the scabbing color between skin sections show variations of green and brown scabbing between sections. While observations on the scabbing color in center of skin section shows there is no variation. Scabbing color in the center of skin section has a brown color.

Observations on the character of the fruit flesh color also showed variations. Breadfruit in Bawean Island has a creamy or light yellow flesh color of fruit. Breadfruit also has a variety of latex colors. The latex color of breadfruit observed during the survey was reddish and white.

Breadfruit observed had 625 grams to 2486 grams weight. It has a length of $24 \mathrm{~cm}$ and the width of the fruit reaches $18 \mathrm{~cm}$ in the middle of the fruit and reaches 12.5 $\mathrm{cm}$ at the top and bottom of the fruit. In the center of the breadfruit, there is a core that has a length of $6.5 \mathrm{~cm}$ to 15 $\mathrm{cm}$ and a core width of 2.5 to $4 \mathrm{~cm}$. Breadfruits have a peduncle length of around $5 \mathrm{~cm}$ to $11.5 \mathrm{~cm}$.

Table 1. Geographic distribution of the studied 30 breadfruit sample accessions in Bawean Island, Gresik, Indonesia

\begin{tabular}{lllll}
\hline $\begin{array}{c}\text { Acc. } \\
\text { no. }\end{array}$ & \multicolumn{1}{c}{ Village } & Subdistrict & Latitude & Longitude \\
\hline DN 1 & Daun & Sangkapura & -5.83551 & 112.70337 \\
DN 2 & Daun & Sangkapura & -5.83408 & 112.70455 \\
KBG & Klumpanggubug & Tambak & -5.75044 & 112.64651 \\
SKO & Sukaoneng & Tambak & -5.75857 & 112.63097 \\
DPG 1 & Diponggo & Tambak & -5.73568 & 112.69972 \\
DPG 2 & Diponggo & Tambak & -5.73390 & 112.69936 \\
PTS & Patar Selamat & Sangkapura & -5.84183 & 112.65657 \\
GLM & Gelam & Tambak & -5.76195 & 112.62456 \\
KTD 1 & Kebun teluk dalam & Sangkapura & -5.81559 & 112.69797 \\
KTD 2 & Kebun teluk dalam & Sangkapura & -5.81188 & 112.69469 \\
KTD 3 & Kebun teluk dalam & Sangkapura & -5.81227 & 112.69457 \\
PKL 1 & Pekalongan & Tambak & -5.74210 & 112.64670 \\
PKL 2 & Pekalongan & Tambak & -5.74206 & 112.64637 \\
SKL & Sukalila & Tambak & -5.75032 & 112.64469 \\
GJG 1 & Grejeg & Tambak & -5.75243 & 112.66771 \\
GJG 2 & Grejeg & Tambak & -5.75161 & 112.66786 \\
PRM & Paromahan & Tambak & -5.77059 & 112.68084 \\
TJO & Tanjung ori & Tambak & -5.72936 & 112.67943 \\
KPT 1 & Kepuh Teluk & Tambak & -5.75489 & 112.72386 \\
KPT 2 & Kepuh Teluk & Tambak & -5.75369 & 112.72373 \\
KPT 3 & Kepuh Teluk & Tambak & -5.75370 & 112.72359 \\
KPL 1 & Kepuh Legundi & Tambak & -5.76023 & 112.72368 \\
KPL 2 & Kepuh Legundi & Tambak & -5.76298 & 112.72391 \\
PDT 1 & Pudakit Timur & Sangkapura & -5.81645 & 112.61844 \\
PDT 2 & Pudakit Timur & Sangkapura & -5.81985 & 112.61889 \\
DKA 1 & Deket Agung & Sangkapura & -5.80853 & 112.58294 \\
DKA 2 & Deket Agung & Sangkapura & -5.80780 & 112.57570 \\
SDGB & Sidogedung Batu & Sangkapura & -5.80132 & 112.72025 \\
GTH & Gunung Teguh & Sangkapura & -5.83750 & 112.66138 \\
SWR & Suwari & Sangkapura & -5.81314 & 112.60636 \\
\hline
\end{tabular}




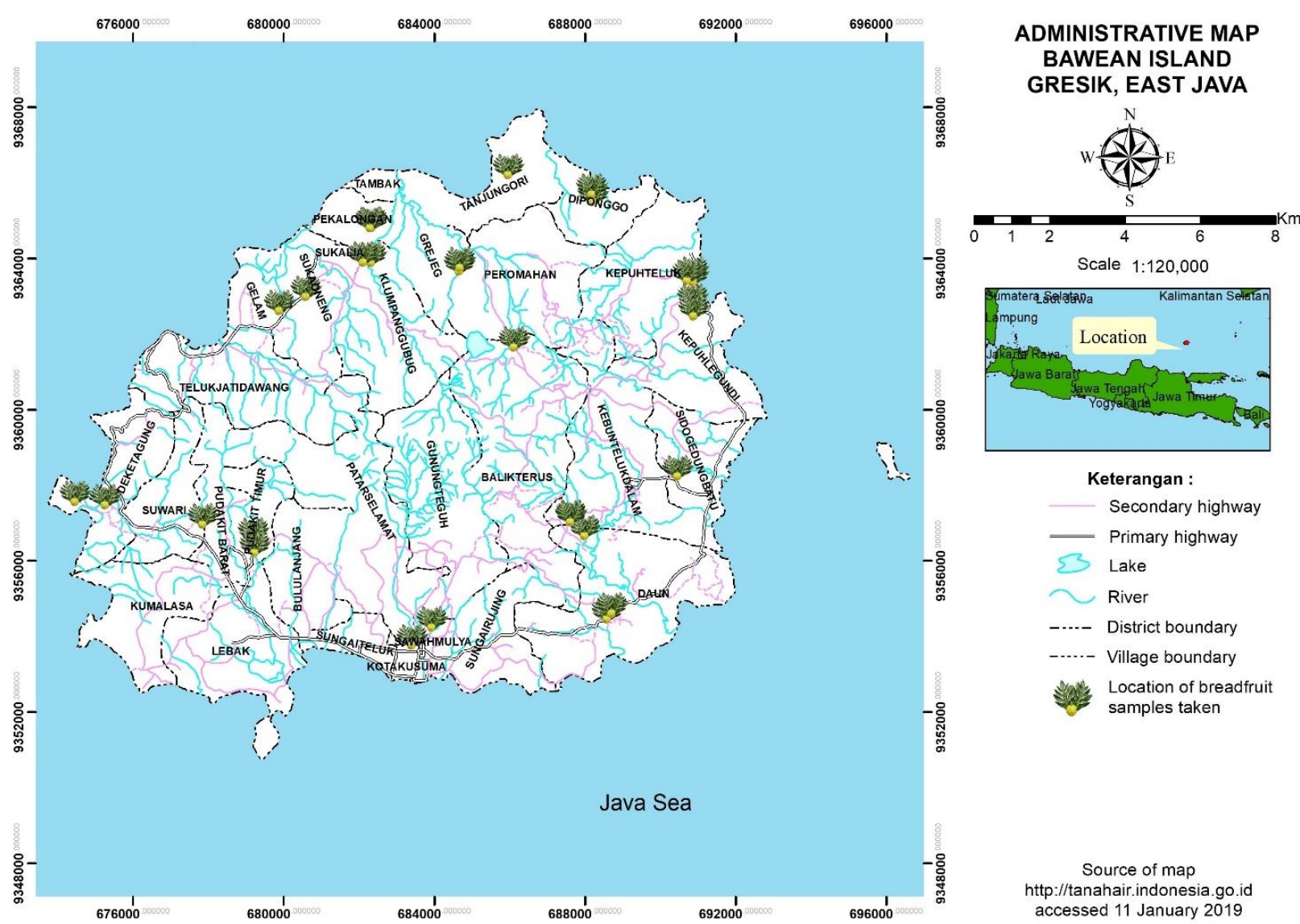

Figure 1. Geographic distribution of the studied 30 breadfruit sample accessions in Bawean Island, Gresik District, East Java, Indonesia

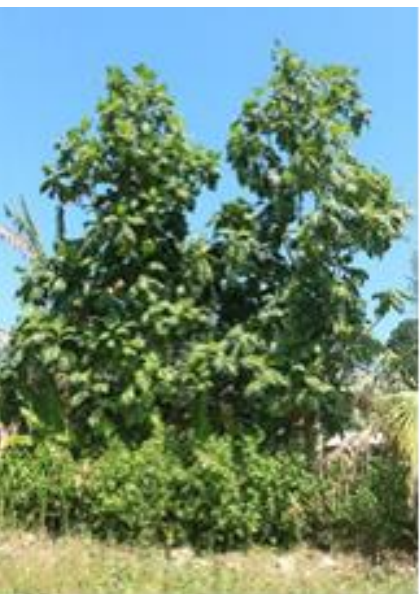

A

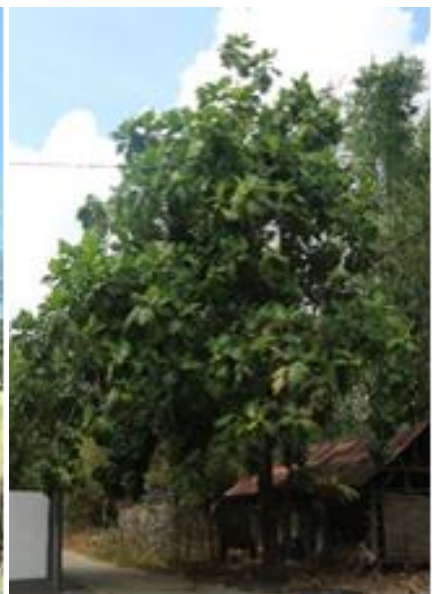

B

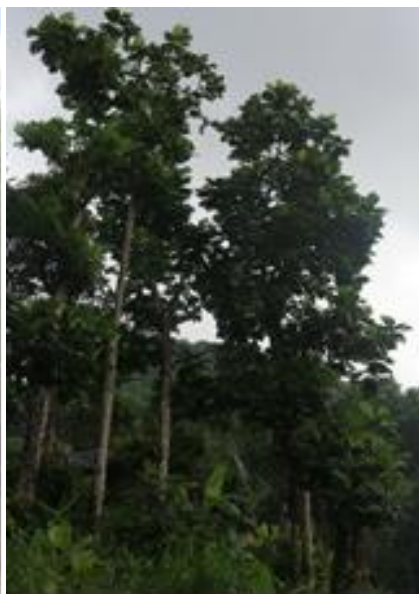

C

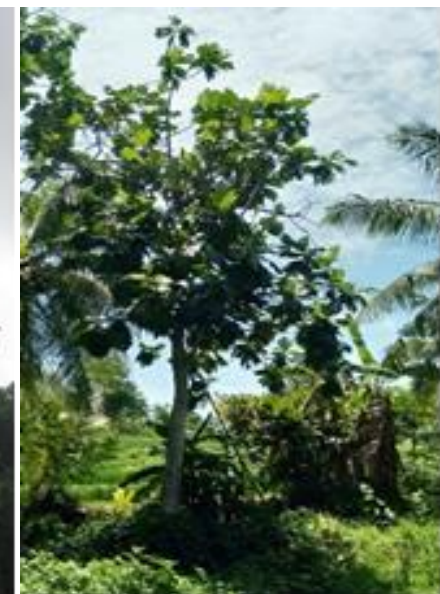

D

Figure 2. Crown shape variation of breadfruit. A. Pyramidal (DN2); B. Wide pyramid (KBG); C. Elliptical (PRM); D. Irregular (KTD1)

Based on the data of varieties descriptions from (Pusat Perlindungan Varietas Tanaman dan Perizinan Pertanian 2019), some characteristics of Bawean breadfruit has similar characteristics with the 3 released breadfruit varieties and 4 breadfruit varieties that have been registered. Some others are different. While the comparison of the characteristic between Bawean breadfruit and varieties of breadfruit that have been released and registered are as follows (Table 2). Padaidi, Manis, and Tado'puli are the breadfruit varieties that have been released. Puloseribu, Bangsyamlan, Iriana, and TengahTengah are the breadfruit varieties that have been registered. 


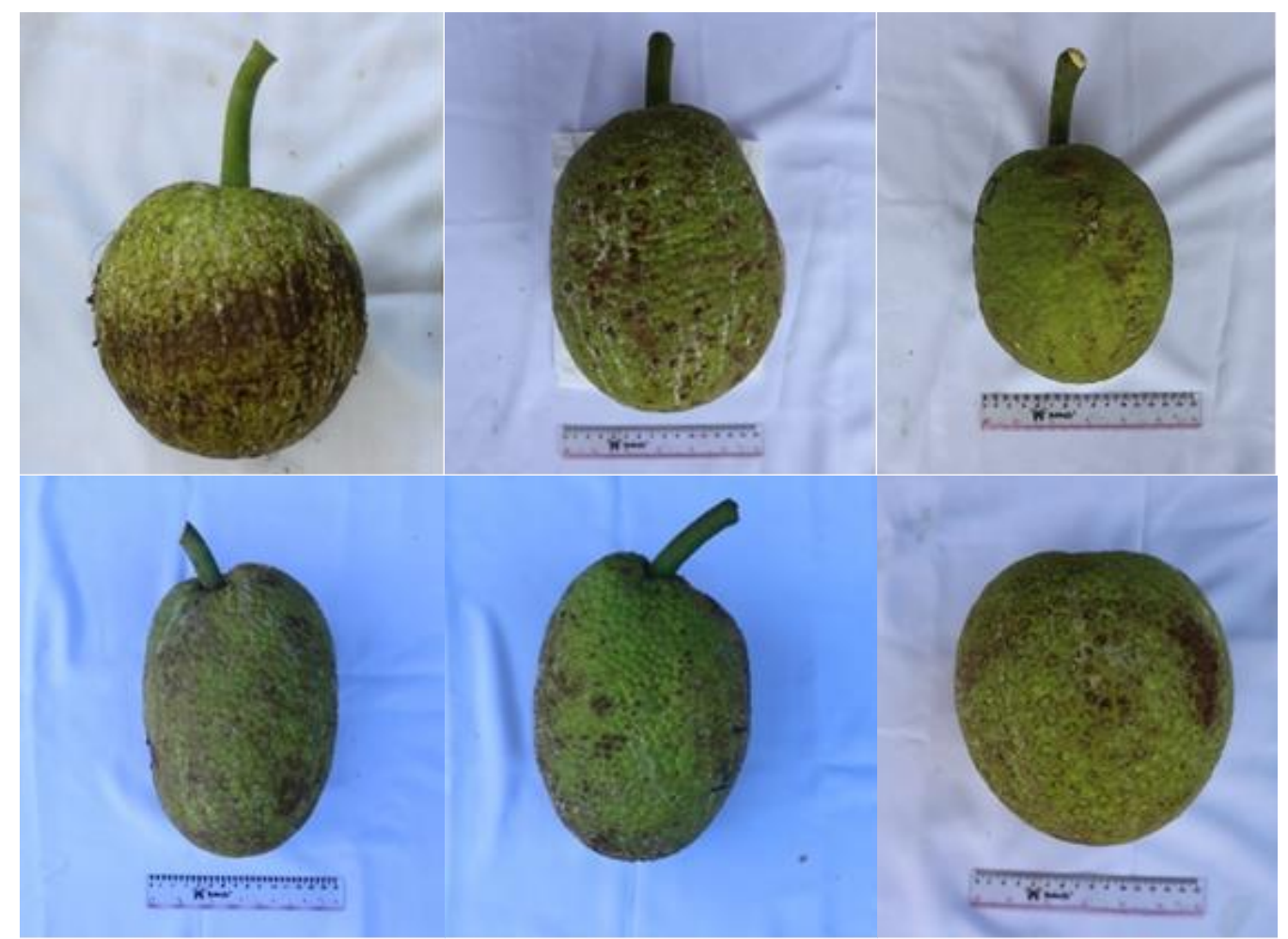

Figure 4. Fruit shape of breadfruit. A. Spherical (DN1); B. Broad ovoid ( KPL1); C. Oval (KPT2); D. Oblong (KTD2); E. Ellipsoid (KTD1); F. Heart-shape (GJG1)

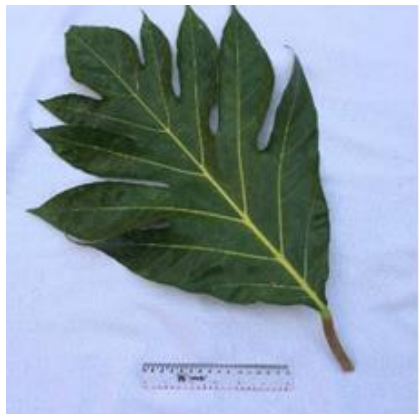

A

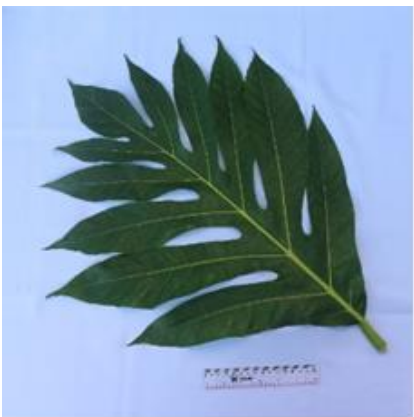

B

Figure 3. Leaf Dissection variation of breadfruit. a. moderately dissected (PTS); b. deeply dissected (GLM)

\section{Genetic distance of breadfruit plants in Bawean Island}

Analysis of genetic distance on qualitative characters showed that 30 accessions of breadfruit were found have similarity coefficient values clustered at 0.0168 to 0.9999 (Figure 5.a). Thirty breadfruit accessions were divided into 3 groups at a similarity coefficient of 0.3635 . The first group consisted of 19 accessions having similarities in leaf dissection, shape of leaf apex, fruit skin texture and scabbing color in center of skin section. The second group consists of 2 accessions that have similarities in leaf surface character and shape of leaf base. The third group consisted of 9 accessions that has similarities in the shape of leaf apex, fruit skin texture, scabbing in center of skin section, scabbing color between skin section, scabbing

color in center of skin section and fruit flesh color. While the genetic distance analysis on quantitative characters showed that 30 accessions of breadfruit were found have a similarity coefficient values clustered at 0.9987 to 0.9999 (Figure 5.b). Thirty breadfruit accessions are divided into 5 groups at a similarity coefficient of 0.9998 . The separation of some groups occurred because of the differences in the character of fruit weight and fruit length.

Analysis of genetic distance on qualitative and quantitative characters showed different grouping results. Quantitative characters have a greater number of groups than those in the qualitative characters. It occurs because of other factors beyond genetic factors that affect a quantitative character. In addition, the qualitative character has a far genetic distance between accessions, while the quantitative character has a very close distance between accessions. It because the qualitative and quantitative characters are a matrix. This means that although it's different qualitatively, it can be similar or the same quantitatively.

Thirty accessions of breadfruit plants found have a similarity coefficient value clustered at 0.9984 to 0.9999 on a combination of qualitative and quantitative characters (Figure 6). Thirty breadfruit accessions are divided into 6 groups at a similarity coefficient value of 0.9998 . Although the results of the analysis showed a grouping, the similarity coefficient values for the 30 accessions approaching the value of one indicate that the breadfruit accession was found to have a close kinship. 
Table 2. Characteristics comparison between Bawean breadfruit and varieties of breadfruit that have been released and registered

\begin{tabular}{|c|c|c|c|c|c|c|c|c|}
\hline \multirow{2}{*}{ Characters } & \multirow{2}{*}{$\begin{array}{l}\text { Bawean breadfruit } \\
\text { (This study) }\end{array}$} & \multicolumn{7}{|c|}{ Released and registered varieties *) } \\
\hline & & Padaidi & Manis & Tado'puli & Pulo Seribu & Bangsyamlan & Iriana & Tengah-Tengah \\
\hline Crown shape & $\begin{array}{l}\text { Pyramidal, wide pyramid, elliptical } \\
\text { and irregular }\end{array}$ & Wide pyramid & Elliptical & Wide pyramid & - & - & Wide pyramid & Wide pyramid \\
\hline Leaf color & Green and dark green & Dark green & Dark green & Dark green & Dark green & Green & Green & Dark green \\
\hline Leaf surface & Glossy and dull & Glossy & Glossy & Glossy & - & Glossy & Glossy & Dull \\
\hline Shape of leaf apex & Diamond & Diamond & Diamond & Diamond & - & Diamond & - & - \\
\hline Shape of leaf base & Acute, rounded and cuneate & - & - & - & - & Acute & Rounded & - \\
\hline Fruit shape & $\begin{array}{l}\text { Spherical, broadly ovoid, oval, } \\
\text { oblong, ellipsoid and heart-shape }\end{array}$ & - & Broad ovoid & Oval & - & Oval & Oval & Oval \\
\hline Skin texture & Smooth and flattened pebbly & - & Smooth & $\begin{array}{l}\text { Spiny with pointed } \\
\text { flexible tip }\end{array}$ & - & $\begin{array}{l}\text { Spiky with hard } \\
\text { raised center point }\end{array}$ & $\begin{array}{l}\text { Spiny with pointed } \\
\text { flexible tip }\end{array}$ & $\begin{array}{l}\text { Spiky with hard } \\
\text { raised center point }\end{array}$ \\
\hline Skin color & Light green and yellow-green & Yellow-green & Brown & - & Yellow-green & Yellow-green & Yellow-green & Green \\
\hline Fesh color & Creamy and light yellow & Creamy & Creamy & Creamy & Creamy & Light yellow & - & - \\
\hline Leaf length $(\mathrm{cm})$ & $37-78$ & - & $11-13.6$ & - & - & $46-62$ & $49-65$ & $38.1-40.4$ \\
\hline Leaf width $(\mathrm{cm})$ & $28-64$ & - & $4.6-5.5$ & - & - & $34-47 \mathrm{~cm}$ & $42-53.7 \mathrm{~cm}$ & $40.4-60.4$ \\
\hline Number of lobes & $7-9$ & - & - & - & - & - & $7-9$ & - \\
\hline Petiole length $(\mathrm{cm})$ & $3.5-9$ & $6-7$ & - & $7-8$ & 5 & $4.5-7$ & $6.8-7.5$ & $6.2-7.8$ \\
\hline Flower length $(\mathrm{cm})$ & 20 & - & - & - & - & - & $6.5-30$ & - \\
\hline Flower diameter $(\mathrm{cm})$ & 3 & - & $6-8$ & - & - & - & $2.6-5.1$ & - \\
\hline Fruit weight (g) & $625-2486$ & $800-1100$ & $1200-1500$ & $900-1200$ & $1500-2000$ & $1200-1700$ & $2000-4500$ & $2200-2400$ \\
\hline Fruit length $(\mathrm{cm})$ & $11-24$ & - & $7.5-9$ & - & - & $18-24.7$ & $20.3-27.0$ & $19.6-22.3$ \\
\hline Fruit width at middle $(\mathrm{cm})$ & $11-18$ & - & - & - & - & $11.5-14$ & $16.5-18$ & - \\
\hline Core length $(\mathrm{cm})$ & $6.5-15$ & - & - & - & 6 & - & - & - \\
\hline Peduncle length $(\mathrm{cm})$ & $4-11.5$ & $6-7$ & $2-4$ & - & - & - & - & - \\
\hline
\end{tabular}

Note: Pusat Perlindungan Varietas Tanaman dan Perizinan Pertanian (2019) 

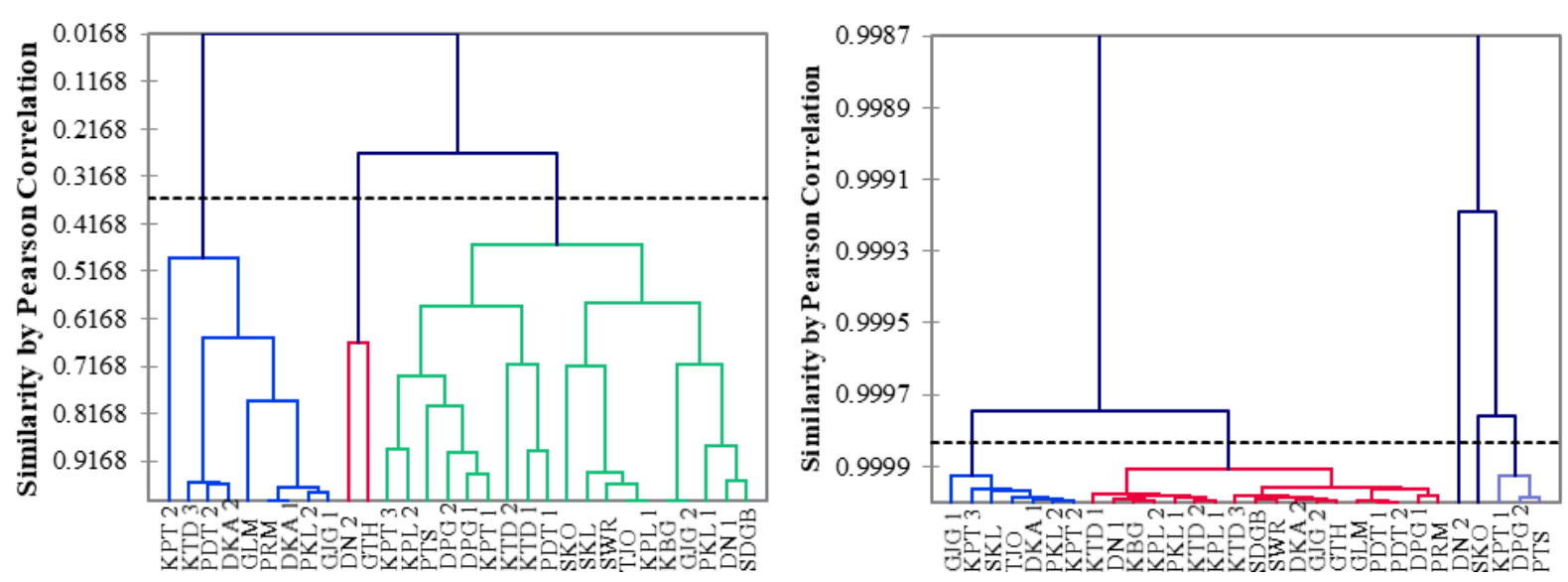

Figure 5. Dendrogram of 30 breadfruit accession analyzed by UPGMA. A. Based on qualitative characters; B. Based on quantitative characters

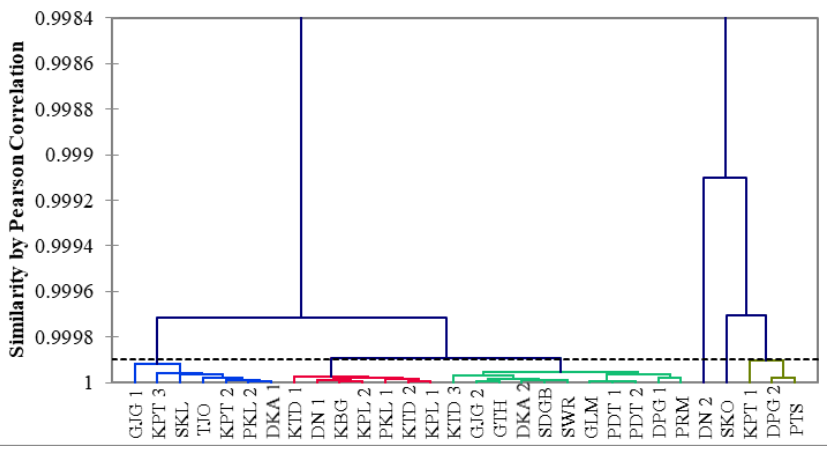

Figure 6. Dendrogram of 30 breadfruit accession analyzed by UPGMA based on a combination of qualitative and quantitative characters

This study is in accordance with the research of Ifah et al. (2018) who analyzed nine accessions of breadfruit plants from Yogyakarta. The study also showed that the majority of members in each group of the 9 accessions had a similarity coefficient value above 0.8 , pointing towards close kinship. According to Ifah et al. (2018), the morphological variations may arise due to variations in environmental factors such as soil type and condition, rainfall, climate, whereas factors such as mutations or the human intervention are also known to influence the process of genetic variation.

\section{Diversity of breadfruit plants in Bawean Island and their conservation status}

Analysis of breadfruit plant diversity in Bawean Island showed Shannon-Wiener diversity index $\left(\mathrm{H}^{\prime}\right)$ value of 1.48 indicating medium diversity, even though, the dendrograms are showing 6 clusters and possibly 6 varietal lines of breadfruit in the Island. Two very interesting reasons behind the moderate breadfruit diversity in the Island may be due to (i) the common practice of local propagation of breadfruit plants in the Island in form of root cuttings (ii) and the breadfruit plants existing in the Island were seedless due to parthenocarpy. This was corroborated by the study of Zerega et al. (2005) who reported that Polynesian breadfruit has lower diversity than Micronesia and Melanesian breadfruit because the dominant Polynesian breadfruit is propagated vegetatively. As it was noticed that cross-pollinated flowers would also produce seedless fruits, therefore ways to initiate seeded fruits need to be found out to increase genetic diversity (Ragone 2001). According to Bhandari et al. (2017), evolutionary abilities such as selection, mutation, and migration can produce changes in allelic frequencies in a population and affect genetic diversity. As Bawean Island is seen as native area of the breadfruit plants in Indonesia, it needs to be thoroughly investigated through genetic markers to find out novel lines of breadfruit for their breeding and conservation of germplasm. Further, it was found that there was general lack of awareness among the local people of the Bawean Island regarding the role of breadfruit trees in food security at times of environmental degradation, eco-restoration of degraded sites, low maintenance - high nutrition crop and nurturing of public health (Langton and Lincoln 2018) as it was noticed that many breadfruit trees had been felled while others were in line. Therefore, it is thought necessary to aware and sensitizes locals regarding the importance, prospects, and methods of sustainable cultivation and utilization of breadfruits on the Island.

\section{ACKNOWLEDGEMENTS}

Dedicating Program Doktor Mengabdi 2018-2019 of Brawijaya University, Malang, Indonesia chaired by Dr. Budi Waluyo

\section{REFERENCES}

Badrie N, Broomes J. 2010. Beneficial uses of breadfruit (Artocarpus altilis): Nutritional medicinal and other uses. Bioactive Foods in Promoting Health. Elsevier Inc., Dordrecht. 
Bhandari H, Bhanu AN, Srivasta K, Singh M, Shreya, Hemantarajan A 2017. Assessment of genetic diversity in crop plants-an overview. Adv Plants Agric Res 7: 279-286. DOI: 10.15406/apar.2017.07.00255.

BMKG. 2019. Data Iklim Harian. http://dataonline.bmkg.go.id/akses_data

Etikan I, Musa SA, Alkassim RS. 2016. Comparison of convenience sampling and purposive sampling. Am J Theor Appl Stat 5: 1-4. DOI: 10.11648/j.ajtas.20160501.11.

Ifah AA, Yuniastuti E, Parjanto. 2018. Analysis of breadfruit plant diversity (Artocarpus altilis P .) by random amplified polymorphic DNA (RAPD) in DIY. AIP Conf Proc. 2021 070004. DOI: 10.1063/1.5062802.

Ijarotimi SO, Aroge F. 2005. Evaluation of the nutritional composition, sensory and physical properties of potential weaning food from locally available food materials - breadfruit (Artocarpus altilis) and soybean (Glycine max). Polish J. Food Nutr. Sci. 14: 411-415.

Jones AMP, Murch SJ, Wiseman J, Ragone D. 2013. Morphological diversity in breadfruit (Artocarpus, Moraceae: insights into domestication, conservation, and cultivar identification. Genet Resour Crop Evol 60: 175-192. DOI: 10.1007/s10722-012-9824-8.

Magurran AE. 1988. Diversity indices and species abundance models. Ecological Diversity and Its Measurement. Springer, Dordrecht.

Olaoye OA, Onilude AA, Oladoye CC. 2007. Breadfruit flour in biscuit making: effects on product quality. Afr J Food Sci 10: 20-23.

Pusat Perlindungan Varietas Tanaman dan Perizinan Pertanian. 2019 Pusat Perlindungan Varietas Tanaman dan Perizinan Pertanian. Kementerian Pertanian, Republik Indonesia, Jakarta. [Indonesian]
Ragone D. 1997. Breadfruit, Artocarpus altilis (Parkinson) Fosberg. In: Engels JMM (ed.). Promoting the Conservation and Use of Underutilized and Neglected. IPGRI, Rome, Italy.

Ragone D. 2006. Artocarpus altilis (Breadfruit). Species Profiles Pacific Isl Agrofor. (April 2006): 1-17. www.traditionaltree.org.

Ragone D, Wiseman J. 2007. Developing and applying descriptors for breadfruit germplasm. Acta Hortic 757: 71-80. DOI: 10.17660/ActaHortic.2007.757.8.

Roberts-Nkrumah LB. 2015. Breadfruit and Breadnut Orchard Establishment and Management. FAO, Rome.

Sistem Informasi Database Varietas Tanaman Kementerian Pertanian R.I. 2019. Sistem Informasi Database Varietas Tanaman Kementerian Pertanian R.I. Kementerian Pertanian, Republik Indonesia, Jakarta. [Indonesian]

Tamegnon AK, Innocent YB, Celestin TCK, Roseline B, Pivot SS, Anayce DA, Jultesse BSB, Paulin A. 2017. Uses of the fruit of breadfruit tree (Artocarpus altilis) in the Republic of Benin: Bibliographic Synthesis. Intl J Agron Agric Res 11: 69-81.

USDA. 2018a. Basic Report 09059, Breadfruit, raw. Natl. Nutr. Database Stand. USDA, Washington, DC.

USDA. 2018b. Basic Report 20050, Rice, white, medium-grain, raw, enriched. Natl. Nutr. Database Stand. USDA, Washington, DC.

Zerega N, Ragone D, Motley TJ. 2005. Breadfruit origins, diversity and human-facilitated distribution. Darwin's Harvest: New Approaches to Origins, Evolution, and Conservation of Crop Plants. Columbia University Press, New York. 